\title{
Response to an oral calcium load in nephrolithiasis patients with fluctuating parathyroid hormone and ionized calcium levels
}

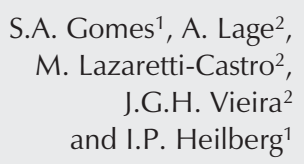

S.A. Gomes ${ }^{1}$, A. Lage ${ }^{2}$,

M. Lazaretti-Castro ${ }^{2}$, J.G.H. Vieira ${ }^{2}$ and I.P. Heilberg ${ }^{1}$

Departamentos de ${ }^{1}$ Nefrologia and ${ }^{2}$ Endocrinologia, Universidade Federal de São Paulo, São Paulo, SP, Brasil

\section{Correspondence \\ I.P. Heilberg \\ Departamento de Nefrologia \\ Universidade Federal de São Paulo \\ Rua Botucatu, 740 \\ 04023-900 São Paulo, SP \\ Brasil \\ Fax: +55-11-5573-9652 \\ E-mail: ipheilberg@nefro.epm.br}

Part of this study was presented at the 35th Annual Meeting of the American Society of Nephrology, Philadelphia, PA, USA, October 2002.

Research supported by CNPq and Fundação Oswaldo Ramos.

Publication supported by FAPESP. .....................

Received September 29, 2003 Accepted May 25, 2004

\begin{abstract}
The response to an oral calcium load test was assessed in 17 hypercalciuric nephrolithiasis patients who presented elevated parathyroid hormone (PTH) irrespective of the ionized calcium $\left(\mathrm{sCa}^{2+}\right)$ levels. Blood samples were collected at baseline $(0 \mathrm{~min})$ and at 60 and 180 min after $1 \mathrm{~g}$ calcium load for serum PTH, total calcium, $\mathrm{sCa}^{2+}$, and $1.25(\mathrm{OH})_{2} \mathrm{D}_{3}$ determinations. According to the $\mathrm{sCa}^{2+}$ level at baseline, patients were classified as normocalcemic $(\mathrm{N}=9)$ or hypercalcemic $(\mathrm{N}=8)$. Six healthy subjects were also evaluated as controls. Bone mineral density was reduced in $14 / 17$ patients. In the normocalcemic group, mean PTH levels at 0, 60 and 180 min $(95 \pm 76,56 \pm 40,57 \pm$ $45 \mathrm{pg} / \mathrm{ml}$, respectively) did not differ from the hypercalcemic group $(130 \pm 75,68 \pm 35,80 \pm 33 \mathrm{pg} / \mathrm{ml})$ but were significantly higher compared to healthy subjects despite a similar elevation in $\mathrm{sCa}^{2+}$ after 60 and 180 min vs baseline in all 3 groups. Mean total calcium and $1.25(\mathrm{OH})_{2} \mathrm{D}_{3}$ were similar in the 3 groups. Additionally, we observed that 5 of 9 normocalcemic patients presented a significantly higher concentration-time curve for serum PTH $\left(\mathrm{AUC}_{0^{\prime}, 60^{\prime}, 180^{\prime}}\right)$ than the other 4 patients and the healthy subjects, suggesting a primary parathyroid dysfunction. These data suggest that the individual response to an oral calcium load test may be a valuable dynamic tool to disclose a subtle primary hyperparathyroidism in patients with high PTH and fluctuating $\mathrm{sCa}^{2+}$ levels, avoiding repeated measurements of both parameters.
\end{abstract}

Key words

- Parathyroid hormone

- Calcium

- Hyperparathyroidism

- Hypercalciuria

- Nephrolithiasis

- Bone mineral density ...................

\section{Introduction}

Primary hyperparathyroidism is characterized by inappropriately increased secretion of parathyroid hormone (PTH) in relation to the serum calcium level of the patient. Clinically the disorder is accompanied by hypercalcemia, serum levels of intact PTH within or above the upper normal range and an increased parathyroid cell mass (1).

The incidence of nephrolithiasis in primary hyperparathyroidism is 10 to $30 \%$ and hypercalciuria is only present when the filtered calcium load exceeds the maximum ability of renal tubular reabsorption of calcium induced by PTH $(2,3)$. The increase of 
total serum calcium in hyperparathyroidism is not always demonstrable and several measurements may be needed to ensure that hypercalcemia is present. Although hypercalcemia is a key feature in establishing the diagnosis of primary hyperparathyroidism, the possibility of the existence of hyperparathyroidism with intermittent or no elevation in total serum calcium has been raised by several investigators since the first description of normocalcemic hyperparathyroidism in 1953 (4-8).

On the other hand, the suspicion of normocalcemic primary hyperparathyroidism may be raised on the basis of a history of recurrent renal calculi and increased urine calcium excretion. Primary hyperparathyroidism is observed in 1 to $5 \%$ of all calcium stone formers (9). However, about $50 \%$ of patients with renal calculi have idiopathic hypercalciuria, a condition associated with normocalcemia as determined by total serum calcium. Despite initial evidence of secondary hyperparathyroidism due to chronic renal tubular calcium leakage, many investigators have not confirmed it (10-14).

It has been reported that the measurement of ionized calcium is more sensitive than total serum calcium to indicate hyperparathyroidism $(5,15)$.

Levels of intact PTH even when determined by optimal two-site immunoassays may reflect measurement of molecules with no bioactivity (16). Thus, the overestimation of PTH impairs the diagnosis of subtle primary hyperparathyroidism. In addition, there is an intrinsic physiologic variation in serum PTH levels. Therefore, several measurements of both PTH and ionized calcium are needed to diagnose parathyroid dysfunction in patients with intermittent or no elevation of total serum calcium.

Although there are distinct pathophysiologic mechanisms, failure to separate the rare patient with normocalcemic primary hyperparathyroidism from the idiopathic hypercalciuria patients with eventual sec- ondary hyperparathyroidism has led to inappropriate neck exploration (17).

We hypothesized that an oral calcium load test could detect a dynamic response by the parathyroid glands, providing better evaluation of parathyroid dysfunction, rather than multiple determinations of PTH and ionized calcium.

\section{Patients and Methods}

Informed written consent to participate was obtained from each patient and the study was approved by the Ethics Committee of Universidade Federal de São Paulo.

Seventeen outpatients (14 women and 3 men; mean age $48 \pm 13$ years) from the Nephrology or Endocrinology Divisions presenting high serum PTH levels irrespective of total and ionized calcium levels, hypercalciuria and or nephrolithiasis, were included in the study.

Patients with chronic renal failure, endocrinological disorders such as hyperthyroidism, acromegaly, sarcoidosis, diabetes mellitus, or neoplasias, or taking drugs which could not be withdrawn during the protocol (corticosteroid, diuretics, oral contraceptives, etc.) were excluded. All patients were instructed by a dietitian to follow the same dietary recommendations (i.e., calcium intake of $500 \mathrm{mg} / \mathrm{day}$ and sodium chloride intake of $140 \mathrm{mEq} /$ day) 2 weeks before the test was performed. A control group matched for calcium intake, consisting of 6 healthy volunteers ( 4 women and 2 men; mean age: $26 \pm 4$ years) was studied.

\section{Urinary calcium}

A 24-h urine sample was obtained from 15 patients for calcium determination. Hypercalciuria was defined as urinary calcium $>250$ $\mathrm{mg} / 24 \mathrm{~h}$ for females, $>300 \mathrm{mg} / 24 \mathrm{~h}$ for males and/or $\geq 4 \mathrm{mg} \mathrm{kg}^{-1} 24 \mathrm{~h}^{-1}$ for either sex (18).

Acute calcium load test. All patients and controls were maintained on their regular 
diet before the test. Blood and urine samples consecutively obtained during fasting and after the oral calcium load were analyzed. The patients started fasting soon after dinner (19:00 h) during the evening preceding the test except for $300 \mathrm{ml}$ of distilled water which they drank at 21:00 $\mathrm{h}$ and at midnight. On the test day, the patients drank $300 \mathrm{ml}$ of distilled water at 6:00 h. At 7:00 h a blood sample was drawn for measurements of total and ionized calcium, intact PTH, creatinine, $1.25(\mathrm{OH})_{2} \mathrm{D}_{3}$, and phosphate. Basal urine was collected over a period of $2 \mathrm{~h}$ from 7:00 to 9:00 $\mathrm{h}$ for calcium, creatinine and phosphate determinations. An oral calcium load of $1 \mathrm{~g}$ (as gluconolactate and carbonate; Calcium Sandoz $\mathrm{F}^{\circledR}$, Basel, Switzerland) was then given. The second period began immediately after calcium administration. Another blood sample was collected at 60 and 180 min following the calcium load for total and ionized calcium, phosphate and intact PTH determinations. Ionized calcium was drawn under vacuum venipuncture and immediately centrifuged. In the second urine sample collected $180 \mathrm{~min}$ after the calcium load, calcium, creatinine and phosphate were again determined.

\section{Intact serum parathyroid hormone}

Intact serum PTH was determined by an in-house immunofluorometric assay (normal range: $4-70 \mathrm{pg} / \mathrm{ml}$ ) based on a chicken egg yolk-derived amino-terminal antibody (PTH1-34) bound to a microtiter plate by antichicken Ig monoclonal antibody. A Europium-labeled carboxyl-terminal specific monoclonal antibody produced from a mouse immunized with a PTH-(53-84)-BSA conjugate was employed as the tracer antibody. The intra-assay error was 5\% and the interassay error was $13.4 \%$ (19).

\section{Ionized serum calcium}

Ionized serum calcium was determined by ion selective electrode (AVL Model 9180, Roswell, GA, USA); normal range: $\leq 1.32$ $\mathrm{mmol} / \mathrm{l}$. Total serum calcium was determined by atomic absorption spectrophotometry (Perkin-Elmer Atomic Spectrophotometer 290B, Norwalk, CT, USA); normal range: 8.5 to $10.5 \mathrm{mg} / \mathrm{dl}$. Inorganic phosphate was determined by the Fiske and Subbarow method (20) and creatinine was measured by the alkaline picrate Jaffe reaction (21).

\section{$1.25(\mathrm{OH})_{2} \mathrm{D} 3$ determination}

Serum levels of $1.25(\mathrm{OH})_{2} \mathrm{D}_{3}$ were determined by radioimmunoassay ( ${ }^{123}$ I RIA kit; DiaSorin, Stillwater, MN, USA); normal range: 15.9 to $55.6 \mathrm{pg} / \mathrm{ml}$.

\section{Bone mineral density}

Bone mineral density (BMD) was assessed by dual-energy X-ray absorptiometry at lumbar spine and femoral sites using a DPX-L apparatus (Lunar Radiation Corp., Madison, WI, USA). The criterion for the definition of osteopenia was a hip or spine $\mathrm{BMD}$ value $>1.0 \mathrm{SD}$ below the mean $\mathrm{BMD}$ for the young adult population ( $\mathrm{T}$ score) according to WHO criteria (22).

\section{Parathyroid scintigraphy}

The procedure was carried out using a double-phase study with Tc-99 sestamibi (APEX SPX, Haifa, Israel) (23).

\section{Statistical analysis}

Nonparametric tests were used. The Mann-Whitney test was used for comparison between normocalcemic and hypercalcemic subjects and controls. The Wilcoxon test was used to compare the results obtained before and after the oral calcium load test in the same group. Results are reported as mean \pm SD and statistical significance was defined as $\mathrm{P}<0.05$. 


\section{Results}

Patients' characteristics on admission including individual serum PTH, total and ionized calcium values, urinary calcium, and Tscore are shown in Table 1. Hypercalciuria was detected in 14 of 15 of the 24-h urine samples obtained from all patients. Osteopenia was detected in $14 / 17$ patients, but no fractures were observed. Only 2 patients (numbers 12 and 15) had hyperfunctioning nodules identified by parathyroid scintigraphy (data not shown in Table 1).

\section{Acute calcium load test}

Patients were classified as normocalcemic $(\mathrm{N}=9)$ or hypercalcemic $(\mathrm{N}=8)$ according to the level of ionized calcium determined at baseline ( $0 \mathrm{~min}$ ). The normocalcemic group presented mean ionized calcium similar to the control group at baseline (1.29 \pm 0.04 vs $1.30 \pm 0.01 \mathrm{mmol} / \mathrm{l})$ but significantly lower than the hypercalcemic group $(1.29 \pm 0.04$ vs $1.39 \pm 0.05 \mathrm{mmol} / \mathrm{l})$. A significant difference between the normo- calcemic and hypercalcemic groups was also observed at $60(1.35 \pm 0.05$ vs $1.47 \pm 0.10$ $\mathrm{mmol} / \mathrm{l})$ and $180 \mathrm{~min}(1.39 \pm 0.06$ vs $1.51 \pm$ $0.10 \mathrm{mmol} / \mathrm{l}$ ) but the mean ionized calcium of normocalcemic subjects remained similar to control at 60 and $180 \mathrm{~min}$. When compared to baseline, all 3 groups presented higher mean ionized calcium levels at 60 and 180 min after the load, as shown in Figure 1. In contrast, mean total serum calcium was similar among the normocalcemic, hypercalcemic and control groups at baseline ( 9.7 $\pm 0.4 v s 9.7 \pm 0.5$ and $9.9 \pm 0.4 \mathrm{mg} / \mathrm{dl})$, at 60 $\min (10.0 \pm 0.2 v s 10.4 \pm 0.7 \mathrm{mg} / \mathrm{dl}$ and 10.1 $\pm 0.5 \mathrm{mg} / \mathrm{dl})$ and $180 \mathrm{~min}(10.3 \pm 0.5 \mathrm{vs} 10.3$ \pm 0.7 and $10.3 \pm 0.2 \mathrm{mg} / \mathrm{dl}$ ), respectively.

As shown in Figure 2, the mean PTH of the normocalcemic group was significantly higher than control at baseline $(95 \pm 76 v s 30 \pm 14 \mathrm{pg} /$ $\mathrm{ml}$ ), after $60 \mathrm{~min}$ of calcium load (56 $\pm 40 \mathrm{vs} 17$ $\pm 13 \mathrm{pg} / \mathrm{ml})$ and also after $180 \mathrm{~min}(57 \pm 45 \mathrm{vs}$ $17 \pm 11 \mathrm{pg} / \mathrm{ml})$. However, mean PTH values did not differ between the normocalcemic and hypercalcemic groups at 0,60 or $180 \min (95$ \pm 76 vs $130 \pm 75,56 \pm 40$ vs $68 \pm 35$ and $57 \pm$ 45 vs $80 \pm 33 \mathrm{pg} / \mathrm{ml}$, respectively). There was

\begin{tabular}{|c|c|c|c|c|c|c|c|c|}
\hline \multirow[t]{2}{*}{ Patients } & \multirow{2}{*}{$\begin{array}{l}\text { Gender } \\
\text { (F/M) }\end{array}$} & \multirow{2}{*}{$\begin{array}{c}\text { Age } \\
\text { (years) }\end{array}$} & \multirow{2}{*}{$\begin{array}{c}\text { PTH } \\
\text { (pg/ml) }\end{array}$} & \multirow{2}{*}{$\begin{array}{c}\mathrm{sCa} \\
(\mathrm{mg} / \mathrm{dl})\end{array}$} & \multirow{2}{*}{$\begin{array}{c}\mathrm{Ca}^{2+} \\
(\mathrm{mmol} / \mathrm{l})\end{array}$} & \multirow{2}{*}{$\begin{array}{c}\text { uCa } \\
\text { (mg/24 h) }\end{array}$} & \multicolumn{2}{|c|}{ T-score } \\
\hline & & & & & & & $\mathrm{L}_{2}-\mathrm{L}_{4}$ & Neck \\
\hline 1 & $\mathrm{~F}$ & 29 & 135 & 9.8 & 1.17 & 350 & -1.50 & -0.03 \\
\hline 2 & $\mathrm{~F}$ & 50 & 74 & 8.7 & 1.33 & 262 & 0.29 & -0.66 \\
\hline 3 & $\mathrm{~F}$ & 40 & 70 & 9.8 & 1.37 & 263 & 2.65 & 0.03 \\
\hline 4 & M & 54 & 90 & 9.7 & 1.22 & 337 & -0.81 & -3.14 \\
\hline 5 & $\mathrm{~F}$ & 53 & 75 & 10.0 & 1.29 & 258 & -2.00 & -0.60 \\
\hline 6 & $\mathrm{~F}$ & 72 & 178 & 10.1 & 1.36 & ND & -1.55 & 0.06 \\
\hline 7 & $M$ & 36 & 70 & 9.8 & 1.36 & 395 & -1.39 & -0.81 \\
\hline 8 & $M$ & 29 & 70 & 9.0 & 1.37 & 374 & -1.61 & -1.49 \\
\hline 9 & $\mathrm{~F}$ & 48 & 93 & 9.6 & 1.23 & 302 & -0.52 & -1.90 \\
\hline 10 & $\mathrm{~F}$ & 42 & 74 & 10.2 & 1.29 & 284 & 0.45 & 0.97 \\
\hline 11 & $\mathrm{~F}$ & 54 & 105 & 10.3 & 1.31 & 308 & -1.48 & -0.19 \\
\hline 12 & $\mathrm{~F}$ & 77 & 168 & 10.6 & 1.32 & 145 & -2.93 & -4.26 \\
\hline 13 & $\mathrm{~F}$ & 26 & 70 & 10.2 & 1.37 & 283 & 0.57 & -1.04 \\
\hline 14 & $\mathrm{~F}$ & 61 & 98 & 10.5 & 1.40 & 306 & -2.43 & -0.90 \\
\hline 15 & $\mathrm{~F}$ & 84 & 114 & 11.5 & 1.40 & ND & 0.18 & -2.11 \\
\hline 16 & $\mathrm{~F}$ & 54 & 98 & 10.6 & 1.32 & 370 & 0.94 & -3.20 \\
\hline 17 & $\mathrm{~F}$ & 47 & 140 & 11.1 & 1.42 & 270 & -1.87 & -1.99 \\
\hline
\end{tabular}

$\mathrm{Ca}^{2+}=$ ionized serum calcium; $\mathrm{F}=$ female; $\mathrm{M}=$ male; $\mathrm{PTH}=$ parathyroid hormone; $\mathrm{sCa}=$ total serum calcium; $\mathrm{uCa}=$ urinary calcium. ND $=$ not determined. 
no difference among the normocalcemic, hypercalcemic and control groups in regard to percent PTH suppression from baseline after $60 \min (-40 \pm 11,-46 \pm 17$ and $-54 \pm 20 \%$, respectively) or after $180 \min (-40 \pm 12,-38 \pm$ 15 and $-47 \pm 30 \%$ ).

The serum and urinary parameters obtained during the calcium load test in the normocalcemic group are presented in Table 2 . The table shows that the mean PTH value of patients $1,3,4,6$, and 7 was significantly higher at $0 \mathrm{~min}$ and after 60 and $180 \mathrm{~min}$, respectively $(134 \pm 85,81 \pm 38$ and $81 \pm 57$ $\mathrm{pg} / \mathrm{ml}$ ) when compared to that of patients 2 , 5,8 , and $9(46 \pm 9,25 \pm 5$ and $27 \pm 5 \mathrm{pg} / \mathrm{ml})$ and of healthy subjects $(30 \pm 14,17 \pm 13$ and $17 \pm 11 \mathrm{pg} / \mathrm{ml})$. The mean PTH value for patients 2, 5, 8, and 9 did not differ from that of the healthy subjects. The concentrationtime curve of serum PTH $\left(\mathrm{AUC}_{0^{\prime}, 60^{\prime}, 180^{\prime}}\right)$ for patients $1,3,4,6$, and $7(16,171 \pm 9005 \mathrm{pg}$ $\left.\mathrm{ml}^{-1} \mathrm{~min}^{-1}\right)$ was significantly higher than for patients $2,5,8$, and $9\left(5280 \pm 967 \mathrm{pg} \mathrm{ml}^{-1}\right.$ $\min ^{-1}, \mathrm{P}=0.016$ ) and also than the curve for healthy subjects $(3492 \pm 202, \mathrm{P}=0.004)$. No differences were found in mean urinary $\mathrm{Ca} /$ $\mathrm{Cr}$, or $\mathrm{FeCa} \%$ between patients 1, 3, 4, and 7 and patients 2, 5, 8, and 9, as shown in Table 2 . The mean urinary $\mathrm{Ca} / \mathrm{Cr}$ ratio (data not shown

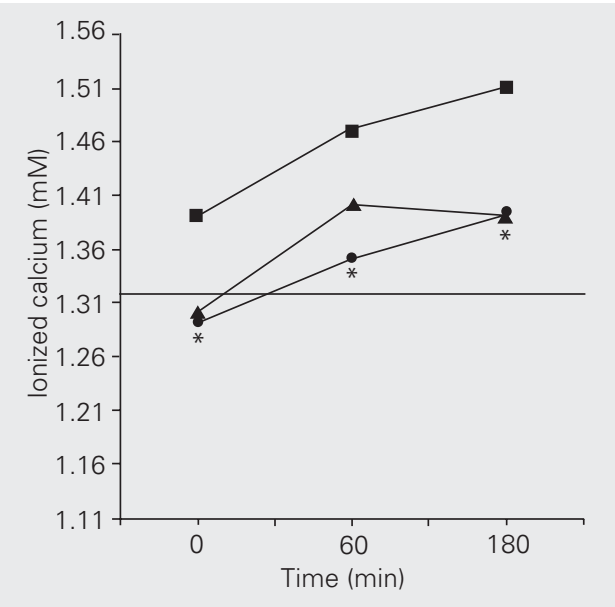

Figure 1. Mean serum ionized calcium levels $\left(\mathrm{Ca}^{2+}\right)$ at baseline $(0 \mathrm{~min})$ and at 60 and 180 min after oral calcium load in hypercalcemic (squares), normocalcemic (circles) and control (triangles) subjects. ${ }^{*} \mathrm{P}<$ 0.05 vs hypercalcemic patients (Mann-Whitney test).

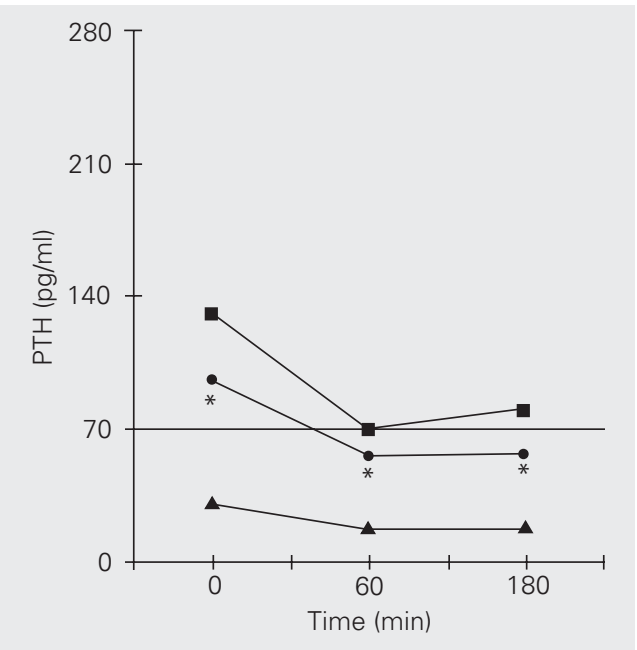

Figure 2. Mean serum parathyroid hormone (PTH) levels at baseline ( $0 \mathrm{~min}$ ) and at 60 and 180 min after oral calcium load in hypercalcemic (squares) normocalcemic (circles) and control (triangles) subjects. ${ }^{*} \mathrm{P}<$ 0.05 vs control subjects (MannWhitney test).

\begin{tabular}{|c|c|c|c|c|c|c|c|c|c|c|c|}
\hline \multirow[t]{2}{*}{ Patients } & \multicolumn{3}{|c|}{$\mathrm{Ca}^{2+}(\mathrm{mmol} / \mathrm{l})$} & \multicolumn{3}{|c|}{ PTH (pg/ml) } & \multirow{2}{*}{$\frac{1.25(\mathrm{OH})_{2} \mathrm{D}_{3}}{0^{\prime}}$} & \multicolumn{2}{|c|}{$\mathrm{Ca} / \mathrm{Cr}$ ratio } & \multicolumn{2}{|c|}{ FECa (\%) } \\
\hline & $0^{\prime}$ & $60^{\prime}$ & $180^{\prime}$ & $0^{\prime}$ & $60^{\prime}$ & $180^{\prime}$ & & $0^{\prime}$ & $180^{\prime}$ & $0^{\prime}$ & $180^{\prime}$ \\
\hline 2 & 1.27 & 1.33 & 1.40 & 40 & 26 & 25 & 42 & 0.11 & 0.18 & 1.0 & 20.6 \\
\hline 5 & 1.31 & 1.48 & 1.50 & 38 & 18 & 22 & 74 & 0.35 & 0.36 & 2.7 & 36.3 \\
\hline 8 & 1.31 & 1.36 & 1.43 & 48 & 29 & 27 & 41 & 0.11 & 0.22 & 1.0 & 21.5 \\
\hline 9 & 1.32 & 1.36 & 1.37 & 59 & 28 & 34 & 21 & 0.20 & 0.22 & 1.9 & 19.6 \\
\hline$X \pm S D$ & $1.30 \pm 0.1$ & $1.38 \pm 0.1$ & $1.43 \pm 0.1$ & $46.0 \pm 9.0$ & $25.0 \pm 5.0$ & $27.0 \pm 5.0$ & $45.0 \pm 21.0$ & $0.19 \pm 0.1$ & $0.24 \pm 0.1$ & $1.7 \pm 0.8$ & $24.5 \pm 7.9$ \\
\hline 1 & 1.17 & 1.26 & 1.26 & 279 & 142 & 159 & 32 & 0.32 & 0.38 & 3.3 & 37.5 \\
\hline 3 & 1.30 & 1.33 & 1.41 & 93 & 50 & 33 & 35 & 0.14 & 0.24 & 1.1 & 24.6 \\
\hline 4 & 1.31 & 1.34 & 1.38 & 72 & 56 & 43 & 59 & 0.14 & 0.22 & 1.3 & 22.2 \\
\hline 6 & 1.31 & 1.36 & 1.39 & 146 & 97 & 99 & 64 & 0.18 & 0.37 & 1.4 & 37.3 \\
\hline 7 & 1.31 & 1.35 & 1.36 & 82 & 60 & 70 & 42 & 0.11 & 0.23 & 1.0 & 22.6 \\
\hline$X \pm S D$ & $1.28 \pm 0.1$ & $1.33 \pm 0.1$ & $1.36 \pm 0.1$ & $134.0 \pm 85.0^{*}$ & $81.0 \pm 38.0^{*}$ & $81.0 \pm 57.0^{*}$ & * $\quad 47.0 \pm 14.0$ & $0.18 \pm 0.1$ & $0.29 \pm 0.1$ & $17 \pm 1.0$ & $29.0 \pm 7.9$ \\
\hline
\end{tabular}

${ }^{*} \mathrm{P}<0.05$ vs mean PTH of patients 2, 5, 8, and 9 (Mann-Whitney test). 
in tables) was significantly higher $v s$ baseline after $180 \mathrm{~min}$ in the normocalcemic $(0.27 \pm 0.1$ vs $0.18 \pm 0.1)$, hypercalcemic $(0.43 \pm 0.2$ vs $0.19 \pm 0.1)$ and control $(0.24 \pm$ 0.1 vs $0.11 \pm 0.1)$ groups. Although the hypercalcemic group tended to show a higher urinary $\mathrm{Ca} / \mathrm{Cr}$ value after $180 \mathrm{~min}$ in comparison to the other 2 groups, the difference did not reach statistical significance.

Mean fractional calcium excretion was significantly elevated after $180 \mathrm{~min}$ of oral calcium load in the normocalcemic (27.0 \pm 7.7 vs $1.7 \pm 0.8 \%)$, hypercalcemic $(44.0 \pm$ 25.0 vs $1.6 \pm 0.5 \%)$ and control $(23.0 \pm 0.11$ vs $0.9 \pm 0.1 \%$ ) groups, but again did not differ among the 3 groups.

Mean fractional phosphate excretion 180 min after the oral calcium load was only significantly lower than baseline in the control group $(3.3 \pm 2.9 v s 9.8 \pm 3.2 \%)$ but not in the normocalcemic or hypercalcemic groups $(10.2 \pm 5.3 v s 10.3 \pm 6.3 \%$ and $10.5 \pm 9.9 v s$ $12.7 \pm 7.0 \%$; data not shown in tables).

The mean values of $1.25(\mathrm{OH})_{2} \mathrm{D}_{3}$ also did not differ between the normocalcemic, hypercalcemic and control groups (46 \pm 17 vs $48 \pm 24$ vs $36 \pm 12 \mathrm{pg} / \mathrm{ml})$. The individual and mean values are presented in Figure 3.

\section{Discussion}

The diagnosis of classic primary hyperparathyroidism is easily established by increased levels of PTH in the presence of hypercalcemia. On the other hand, patients

Figure 3. Individual levels of serum $1.25(\mathrm{OH})_{2} \mathrm{D} 3$ in normocalcemic (circles), hypercalcemic (squares) and control (triangles) groups. Horizontal bars indicate the mean values.

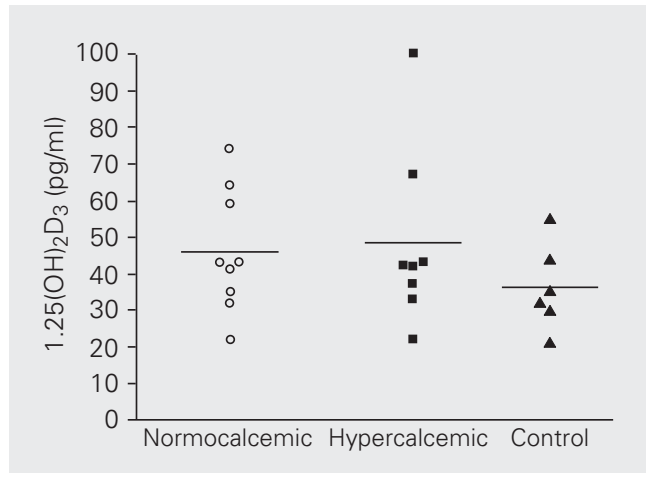

with primary hyperparathyroidism may present significant symptoms and minimal or no elevation in total serum calcium levels (24). Normocalcemic hyperparathyroidism defined as completely normal total serum values is a rare entity that must be searched for in patients with symptoms or complications of hyperparathyroidism, such as renal calculi and bone mineral loss (6). However, the existence of normocalcemic hyperparathyroidism is still controversial (4-7). Another possible explanation for the finding of high levels of PTH with normal serum calcium values is the putative secondary hyperparathyroidism due to renal tubular leakage of calcium in patients with idiopathic hypercalciuria (10-12). Nevertheless, several investigators have reported normal parathyroid function in idiopathic hypercalciuria $(13,14,25)$.

Lundgren et al. (7) found abnormal parathyroid tissue ( $75 \%$ adenomas and $25 \%$ hyperplasias) in $16 / 57$ (28\%) postmenopausal women with high PTH levels and normal ionized and total serum calcium values, suggesting the presence of normocalcemic primary hyperparathyroidism.

The reason why total serum calcium is not increased in patients with primary hyperparathyroidism in the presence of normal serum values of albumin, magnesium, phosphate, and $1.25(\mathrm{OH})_{2} \mathrm{D}_{3}$ is not clear. While some investigators have attributed a normal total calcium level in patients with normocalcemic hyperparathyroidism to an increased ratio of ionized and ultrafiltrable calcium to total calcium in these patients compared to normal subjects, others did not confirm it $(15,26,27)$. Resistance to the effect of PTH in increasing renal tubular reabsorption of calcium resulting in higher urinary calcium has also been postulated (28). Another possibility could be the presence of non-1-84 PTH circulating molecules such as a 7-84 PTH fragment, blocking the calcemic effect of 1-84 PTH and preventing hypercalcemia $(16,29)$.

In the present study, we hypothesized 
that an acute oral calcium load test would help to better evaluate the dynamic response of the parathyroid gland to fluctuations of serum calcium in patients with high serum PTH. The reproducibility of the test was good since the test was easy to perform in an outpatient setting ( 3 blood collections over a period of $180 \mathrm{~min}$ ), as already suggested by other investigators $(30,31)$, with a sensitivity and specificity of 100 and $87 \%$ (31), respectively. Calcium administration was well tolerated by all patients.

In response to the oral calcium load, ionized calcium levels but not total serum calcium levels were increased in normocalcemic, hypercalcemic and control patients. The higher levels of ionized calcium were maintained even after $180 \mathrm{~min}$ in all 3 groups, including the control. These data suggest that ionized calcium is more sensitive than total serum calcium in reflecting acute changes in serum calcium regulation, as also reported by others $(5,15)$.

We observed a higher mean PTH in the normocalcemic group compared to control despite the similar elevation of ionized calcium presented by both. The mean PTH in this normocalcemic group was not significantly different from that presented by the hypercalcemic group, suggesting a disturbance in calcium set point in the former.

A significant difference in the percentage of mean PTH suppression from baseline among the 3 groups was not evidenced in the present study. These findings contrast with those of Monchik et al. (30), who observed a clear-cut separation between normal subjects and patients with high PTH levels and normal total serum calcium, whose PTH suppression achieved values higher and lower than $30 \%$, respectively.

Although the mean percent PTH suppression of the normocalcemic group did not differ from control, we observed that 5 of 9 normocalcemic patients presented a concentration-time curve of serum PTH

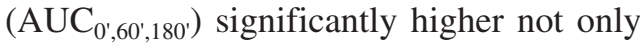

than control but also than the remaining 4 normocalcemic patients. It could be argued that the minimal reduction of PTH in these 5 patients in response to the calcium load might have reflected the detection of inactive long half-life fragments of PTH. Nevertheless, the different response among control patients using the same assay (19), which presents a good correlation $(r=0.938)$ with a commercial immunoradiometric assay (PTHIRMA; Nichols Institute, San Juan Capistrano, CA, USA), does not suggest this hypothesis. On the other hand, according to Silverberg et al. (29), inactive 7-84 PTH fragments may be produced by parathyroid adenomas. It is important to emphasize that although second-generation 1-84 PTH assays present a better diagnostic sensitivity in primary hyperparathyroidism $(16,29)$, they are still not widely available and their diagnostic value is especially important among patients with chronic renal failure.

Our findings suggested a disturbance in calcium set point in the normocalcemic patients when compared to controls. It is noteworthy that even the hypercalcemic group was able to suppress PTH on a percent basis as did the control group but, again, at levels much higher than the normal range.

Recurrent stone formation was the main clinical manifestation and hypercalciuria could be detected in all but one of the normocalcemic patients (8/9).

In fact, hypercalciuria is found in classic primary hyperparathyroidism only if the filtered load of calcium exceeds the threshold for renal tubular calcium reabsorption. Consequently, urinary calcium should not be elevated in normocalcemic hyperparathyroidism patients, but rather in patients with idiopathic hypercalciuria because of the presence of the renal tubular reabsorption defect. In our study, we observed that mean fasting urinary calcium and urinary calcium after calcium load corrected for creatinine excretion and mean fractional calcium excretion did not differ among the 3 groups. 
Following the oral calcium load, a reduction in fractional phosphate excretion was observed only in the control group, reflecting an appropriate PTH suppression in this group. This finding emphasizes the lack of a physiological response of phosphate reabsorption due to the persistent elevation of PTH in both the normocalcemic and hypercalcemic groups.

In the present series, serum $1.25(\mathrm{OH})_{2} \mathrm{D}_{3}$ was similar among the 3 groups, in agreement with Monchik et al. (30), who did not observe an increased $1.25(\mathrm{OH})_{2} \mathrm{D}_{3}$ in hyperparathyroidism patients. Conversely, some investigators observed mild elevations of $1.25(\mathrm{OH})_{2} \mathrm{D}_{3}$ levels in classic hyperparathyroidism $(9,32)$. Although the elevation of $1.25(\mathrm{OH})_{2} \mathrm{D}_{3}$ in idiopathic hypercalciuric patients has been reported by some investigators, others have pointed out high normal values or completely normal values, so that this is still a matter of controversy (32-34).

An elevated frequency of bone mass loss, mainly cortical bone, is often found in primary hyperparathyroidism, as well as in normocalcemic calcium stone formers with idiopathic hypercalciuria, mostly in trabecular bone $(33,35)$. Some investigators have hypothesized that a primary increase in bone resorption due to a monocyte disorder may result in hypercalciuria in these patients $(36,37)$. In our study, we observed osteopenia in 14 of 17 patients with similar distribution of affected sites, lumbar spine or femoral neck.

Parathyroid scintigraphy was not helpful in the diagnosis of hyperparathyroidism in the present study, as also pointed out by other investigators (38).

Although primary hyperparathyroidism patients with the most marked elevation in serum calcium levels are thought to present the most marked symptoms, many investigators have reported that they may present significant symptoms despite a minimal or no elevation in their serum calcium level (4-
$7,24)$. In a series of 142 patients with hypercalcemia, intermittent hypercalcemia or normocalcemia, Siperstein et al. (24) observed a similar frequency of preoperative symptoms and surprisingly the same degree of symptom amelioration after surgery, suggesting that factors other than elevated serum calcium levels are responsible for symptoms of hyperparathyroidism. These investigators also did not find statistical differences in the frequency of single adenomas, hyperplasia or multiple adenomas among these 3 subgroups.

This poses the problem of difficulties regarding the diagnosis of hyperparathyroidism, mainly if the patient is normocalcemic, especially when one is dealing with ionized calcium (39). As we could not easily establish the diagnosis of hyperparathyroidism in these normocalcemic patients despite the high PTH levels, we tested the dynamic response of the parathyroid gland to an oral calcium load. The response to the oral calcium load test among normocalcemic patients showed heterogeneity with respect to PTH levels, irrespective of the clinical manifestation. The maintenance of higher PTH levels, higher than the threshold of 31 $\mathrm{pg} / \mathrm{ml}$ in 5 patients, differing statistically from control, was probably due to an altered calcium set point and suggests that a primary dysfunction of the gland must be present. The concentration-time curve of serum PTH (AUC) of the remaining 4 patients was slightly higher, although not significantly different from control $(5280 \pm 967$ vs $3492 \pm$ 202). On the basis of this response, those 4 patients could be either considered as adequate responders or as presenting secondary hyperparathyroidism. The use of thiazide drugs particularly in these patients in the future might help us to further confirm such hypothesis.

In conclusion, the present study suggests that an oral calcium load test is a valuable dynamic tool in identifying subtle primary hyperparathyroidism in patients with elevated 
PTH and fluctuating ionized calcium levels, avoiding numerous repeated PTH and serum calcium determinations leading to inconclusive results. The test also provides a faster diagnosis determining an earlier therapeutic intervention.

\section{Acknowledgments}

\author{
The authors thank Prof. Omar M. Hauache \\ $\mathrm{MD}, \mathrm{PhD}$, for fruitful discussions, Ilda $\mathrm{S}$. \\ Kunii, for the determination of serum PTH, \\ and Silvia R. Moreira, for technical assistance.
}

\section{References}

1. Grimelius L, Akerstrom G, Johansson H, Juhlin C \& Rastad J (1991). The parathyroid glands. In: Kovaks K \& Asa SL (Editors), Functional Endocrine Pathology. Blackwell Scientific, Oxford, Oxford Shire, England, 375-395.

2. Deaconson TG, Wilson SD \& Lemann JM (1987). The effect of parathyroidectomy on the recurrence of nephrolithiasis. Surgery, 102: 910-913.

3. Mundy GR, Coue DIT \& Fisken R (1980). Primary hyperparathyroidism: changes in the pattern of clinical presentation. Lancet, 1: 13171320.

4. Johannson H, Thoren $L$ \& Werner $L$ (1975). Normocalcemic hyperparathyroidism, kidney stones, and idiopathic hypercalciuria. Surgery, 77: 691-696.

5. Forster J, Monchik JM \& Martin HF (1988). A comparative study of serum ultrafiltrable, ionized, and total calcium in the diagnosis of primary hyperparathyroidism in patients with intermittent or no elevation in total calcium. Surgery, 104: 1137-1142.

6. Monchik JM (1995). Normocalcemic hyperparathyroidism. Surgery, 118: 917-923.

7. Lundgren E, Ridefelt P, Akerström G, Ljunghall S \& Rastad J (1996). Parathyroid tissue in normocalcemic and hypercalcemic primary hyperparathyroidism recruited by health screening. World Journal of Surgery, 20: 727-735.

8. Mather HG (1953). Hyperparathyroidism with normal serum calcium. British Medical Journal, 2: 424-425.

9. Broadus $A E$, Horst RL \& Lang R (1980). The importance of circulating 1.25 dihydroxyvitamin $D$ in the pathogenesis of hypercalciuria and renal-stone formation in primary hyperparathyroidism. New England Journal of Medicine, 302: 421-426.

10. Coe FL, Canterbury JM, Firpo JJ \& Reiss E (1973). Evidence for secondary hyperparathyroidism in idiopathic hypercalciuria. Journal of Clinical Investigation, 52: 134-142.

11. Pak CYC, Kaplan R, Bone H, Towsend J \& Waters O (1975). A simple test for the diagnosis of absorptive, resorptive and renal hypercalciurias. New England Journal of Medicine, 292: 497-500.

12. Broadus $A E$, Lang $R \&$ Kliger AS (1981). The influence of calcium intake and the status of intestinal calcium absorption on the diagnostic utility of measurements of 24-hour cyclic adenosine 3',5'monophosphate excretion. Journal of Clinical Endocrinology and Metabolism, 52: 1085-1089.

13. Olmer M, Berland $Y$ \& Argemi B (1983). Absence of secondary hyperparathyroidism in most patients with renal hypercalciuria. Kidney International, 24: 175-179.

14. Coe FL, Favus MJ, Crokett T, Strauss AL, Parks JH, Porat A, Gant C \& Sherwood LM (1982). Effects of low calcium diet on urine calcium excretion, parathyroid function and serum $1.25(\mathrm{OH})_{2} \mathrm{D}_{3}$ levels in patients with idiopathic hypercalciuria and normal subjects. American Journal of Medicine, 72: 25-32.
15. Monchik JM \& Martin HF (1980). Ionized calcium in the diagnosis of primary hyperparathyroidism. Surgery, 82: 185-192.

16. Gao P, Scheibel S, D'Amour P, John MR, Rao SD, Schmidt-Gayk H \& Cantor TL (2001). Development of a novel immunoradiometric assay exclusively for biologically active whole parathyroid hormone 1-84: implications for improvement of accurate assessment of parathyroid function. Journal of Bone and Mineral Research, 16: 605614.

17. Poole GV, Albertson DA \& Myers RT (1983). Normocalcemic hyperparathyroidism revisited. American Journal of Surgery, 49: 668-671.

18. Hodgkinison A \& Pyrah LN (1958). The urinary excretion of calcium and inorganic phosphate in 344 patients with calcium stone renal origin. British Journal of Surgery, 46: 10-18.

19. Vieira JGH, Nishida SK, Kasamatsu TS, Amarante EC \& Kunii IS (1994). Development and clinical application of an immunofluorometric assay for intact parathyroid hormone. Brazilian Journal of Medical and Biological Research, 27: 2379-2382.

20. Fiske CH \& Subbarow $Y$ (1988). Inorganic phosphate. Journal of Biological Chemistry, 63: 375-400.

21. McFate RP, Cohn C, Eichelberger L \& Cooper JA (1954). Symposium on azotemia. American Journal of Clinical Pathology, 24: 511571.

22. Kanis JA, Melton III LJ, Christiansen C, Johnston CC \& Khaltaev N (1994). The diagnosis of osteoporosis. Journal of Bone and Mineral Research, 9: 1137-1141.

23. Taillefer R, Boucher Y, Potvin C \& Lambert R (1992). Detection and localization of parathyroid adenomas in patients with hyperparathyroidism using a single radionuclide imaging procedure with technetium 99 sestamibi (double phase study). Journal of Nuclear Medicine, 33: 1801-1807.

24. Siperstein AE, Shen W, Chan AK, Duh OY \& Clark OH (1992). Normocalcemic hyperparathyroidism. Archives of Surgery, 127: 1157-1163

25. Lilienfeld-Toal HV, Bach D, Hesse A, Franck H \& Issa S (1982). Parathyroid hormone is normal in renal stone patients with idiopathic hypercalciuria and high fasting urinary calcium. Urology Research, 10: 205-207.

26. Muldoney FP, Freaney R \& McMullin JP (1976). Serum ionized calcium and parathyroid hormone in renal stone disease. Quarterly Journal of Medicine, 45: 75-86.

27. Strott CA \& Nugent CA (1968). Laboratory test in the diagnosis of hyperparathyroidism in hypercalcemic patients. Annals of Internal Medicine, 68: 188-202.

28. Gardin JP \& Paillard M (1984). Normocalcemic hyperparathyroidism resistance to PTH effect on tubular reabsorption of calcium. Mineral and Electrolyte Metabolism, 10: 301-308.

29. Silverberg SJ, Gao P, Brown I, Logerfo P, Cantor TL \& Bilezikian JP (2003). Clinical utility of an immunoradiometric assay for parathyroid 
hormone (1-84) in primary hyperparathyroidism. Journal of Clinical Endocrinology and Metabolism, 88: 4725-4730.

30. Monchik JM, Lamberton RP \& Roth U (1992). Role of the oral calcium-loading test with measurement of intact parathyroid hormone in the diagnosis of symptomatic subtle primary hyperparathyroidism. Surgery, 112: 1103-1110.

31. Hagag P, Revet-Zak I, Hod N, Horne T, Rapoport MJ \& Weiss M (2003). Diagnosis of normocalcemic hyperparathyroidism by oral calcium load. Journal of Endocrinology Investigation, 26: 227-232.

32. Locascio V, Adami S \& Galvanini G (1985). Substrate-product relation of 1-hydroxylase activity in primary hyperparathyroidism. New England Journal of Medicine, 313: 1123-1130.

33. Heilberg IP, Martini LA, Szejnfeld VL, Carvalho AB, Draibe SA, Ajzen $H$, Ramos OL \& Schor N (1994). Bone disease in calcium stone forming patients. Clinical Nephrology, 42: 175-182.

34. Bushinsky DA, Johnston RB, Nalbantian CE \& Favus MJ (1989). Increased calcium absorption and retention, without elevated serum $1.25(\mathrm{OH})_{2} \mathrm{D} 3$ in genetically hypercalciuric rats. Kidney International, 33: 336 (Abstract).

35. Rossini M, Gatti D, Isaia G, Sartori L, Braga V \& Adami S (2001).
Effects of oral alendronate in elderly patients with osteoporosis and mild primary hyperparathyroidism. Journal of Bone and Mineral Research, 16: 113-119

36. Weisinger JR (1996). New insights into the pathogenesis of idiopathic hypercalciuria: The role of bone. Kidney International, 49: 1507-1518

37. Pacifici R, Rothstein M, Rifas L, Lau Kw, Baylink DJ, Avioli LV \& Hruska K (1991). Increased monocyte interleukin-1 activity and decreased vertebral bone density in patients with fasting idiopathic hypercalciuria. Journal of Clinical Endocrinology and Metabolism, 71: 138-145.

38. Castellani M, Reschini E, Longari V, Paracchi A, Corbetta S, Marottha $G$ \& Gerundini $P$ (2001). Role of Tc-99m sestamibi scintigraphy in the diagnosis and surgical decision-making process in primary hyperparathyroid disease. Clinical Nuclear Medicine, 26: 139-144.

39. Bilezikian PJ, Potts JTJ, Fuleihan GEH, Kleerekoper M, Neer R, Peacock M, Rastad J, Silverberg SJ, Uldesman R \& Wells AS (2002). Summary statement from a workshop on asymptomatic primary hyperparathyroidism: A perspective for the 21st century. Journal of Clinical Endocrinology and Metabolism, 87: 5353-5361. 